УДК 629.4.027

\title{
МАГНІТНИЙ КОНТРОЛЬ РІВНЯ НАКОПИЧЕНИХ ВТОМНИХ ПОШКОДЖЕНЬ МЕТАЛОКОНСТРУКЦІЙ ВАНТАЖНИХ ВАГОНІВ
}

Старш. викл. К.В. Шевченко, С.А. Кравченко

\section{МАГНИТНЫЙ КОНТРОЛЬ УРОВНЯ НАКОПЛЕННЫХ УСТАЛОСТНЫХ ПОВРЕЖДЕНИЙ МЕТАЛЛОКОНСТРУКЦИЙ ГРУЗОВЫХ ВАГОНОВ}

Старш. преп. К.В. Шевченко, С.А. Кравченко

\section{MAGNETIC CONTROL LEVEL ACCUMULATED FATIGUE DAMAGE METALS FREIGHT CARS}

\author{
K.V. Shevchenko, S.A. Kravchenko
}

У даній статті розглянуто питання можливості застосування коеричитиметрії при контролі стану металоконструкцій вантажних вагонів. Подано аналіз процесів, які лежать в основі проведення коерцитиметрії. Виявлено та обтрунтовано необхідність застосування коериитиметрії при оцінці поточного стану металоконструкцій вантажних вагонів.

Ключові слова: неруйнівний контроль, структура металу, феромагнетик, коерциитивна сила, напруження металу.

В данной статье рассмотрен вопрос возможности применения коэриитиметрии при контроле состояния металлоконструкций грузовых вагонов. Представлен анализ прочессов, которые лежат в основе проведения коэричттиетрии. Выявлена и обоснована необходимость применения коэричттиетрии при оценке текущего состояния металлоконструкций грузовых вагонов.

Ключевые слова: неразрушающий контроль, структура металла, ферромагнетик, коэриитивная сила, напряжение металла.

In this article the question of the possibility of applying coercimetry in monitoring the state of metal wagons. The analysis of the processes that underlie the conduct coercimetry. Identified and justified the need for coercimetry in assessing the current state of metal wagons.

Keywords: non-destructive testing, metal structure, ferromagnetic, coercive force, tension of the metal.

Постановка проблеми. Оцінка рівня накопичених втомних пошкоджень металоконструкцій, як правило, проводиться за результатами втомних випробувань модельних зразків, виготовлених за технологією, аналогічною досліджуваній конструкції, або вирізаних 3 реальних конструкцій [1].

Вирізання зразків призводить до порушення цілісності конструкції і неможливості її подальшої експлуатації, а визначення рівня накопичених втомних пошкоджень на модельних зразках призводить до спотворення результатів через неминучі відмінності численних факторів, пов'язаних зі структурою i хімічним складом матеріалу, 3 якого виготовлена конструкція. Саме через це існує проблема визначення рівня 
накопичених втомних пошкоджень металоконструкцій вантажних вагонів.

Аналіз останніх досліджень і публікацій. Останніми роками коерцитиметрія [1] стала широко застосовуватися для контролю рівня накопичених втомних пошкоджень металоконструкцій, що $є$ досить актуальним для технічної діагностики несучих елементів вантажних вагонів.

Завдяки досвіду 3 проведення неруйнівного контролю металоконструкцій встановлено [2], що всі зміни в структурі матеріалу в процесі його виготовлення, обробки, зародження i розвитку пошкоджень відображаються у відповідних змінах магнітних $\mathrm{i}$ електрофізичних параметрів. Поява цих змін пояснюється розворотом i переміщенням доменів i міждоменних кордонів, що становлять у сукупності доменну структуру матеріалу.
На рис. 1 умовно показано, що кожне зерно феромагнітного металу розбито на декілька доменів, вектори яких орієнтовані взаємно-протилежно. Середній розмір доменів - від 1 до 10 мікрометрів, тобто кожне зерно містить сотні і тисячі доменів. За відсутності зовнішнього магнітного поля вектори доменів компенсують один одного і загальна намагніченість тіла відсутня. При накладенні зовнішнього поля відбувається зміна доменної структури $\mathrm{i}$ тіло намагнічується. Ті ж самі зміни відбуваються i металоконструкцій вантажних вагонів протягом їх експлуатації.

Прикордонні зміни, що відбуваються в матеріалі металоконструкцій вантажних вагонів, можна відстежувати за допомогою коерцитиметрії, прогнозуючи руйнівні пошкодження, які можуть виникнути внаслідок накопичення втомних пошкоджень.

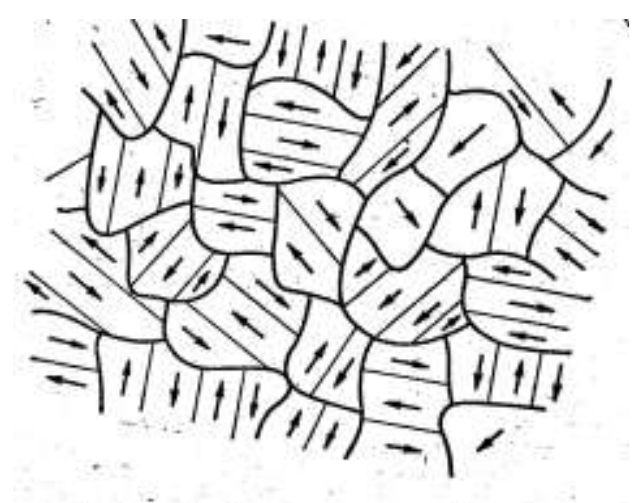

Рис. 1. Доменна структура полікристалічного феромагнетика

Постановка завдання. Фактори невизначеності, які завжди існують у використанні методів неруйнівного контролю, вносять елемент ризику в оцінку рівня накопичених втомних пошкоджень металоконструкцій. У зв'язку із цим виникає необхідність аналізу обраного методу магнітної структуроскопії, щоб можна було його науково-обгрунтовано рекомендувати в практику використання.
Виклад основного матеріалу дослідження. Мікро- та макродефекти структури, накопичуючись у металі в процесі циклічного навантаження при розтягуванні, стисненні, вигині або крученні, ніби збирають i зберігають інформацію, однозначно пов'язану 3 максимальними величинами навантажень, які діяли на металоконструкцію, внаслідок чого структура металу сталевої деталі конструкції виконує функцію своєрідного 
запам'ятовуючого датчика пікового значення сили [3].

Як основний контрольований магнітний параметр обирається величина коерцитивної сили Нс, оскільки вона однозначно пов'язана із залишковою пластичною деформацією $\mathrm{epl}$ при статичному i циклічному навантаженні металоконструкцій у процесі експлуатації. За своєю природою $\mathrm{Hc}$ i $\varepsilon p \mathrm{l}$ взаємопов'язаними зростаючими при циклічному навантаженні, як це можна бачити при аналізі магнітних і деформаційних петель гістерезису, рис. 2 [5]. За своїм фізичним змістом коерцитивна сила Нc - це напруженість магнітного поля, необхідна для повного розмагнічування попередньо намагніченого до насичення феромагнетика (при $\mathrm{B}=0$ щодо граничної петлі гістерезису), і може бути зображена, як:

$$
\mathrm{Hc}=\mathrm{B} / \mathrm{E}+(\mathrm{B} / \mathrm{K}) 1 / \mathrm{n}
$$

де В - залишкова індукція;

К - циклічний коефіцієнт напруги;

$\mathrm{n}$ - циклічний коефіцієнт зміцнення;

Е - модуль пружності.

Залишкова деформація еpl амплітуда необоротної деформації визначається аналогічними параметрами:

$$
\varepsilon p l=\sigma / E+(\sigma / K) 1 / n
$$

де $\sigma$ - амплітуда навантаження;

Е - модуль пружності.
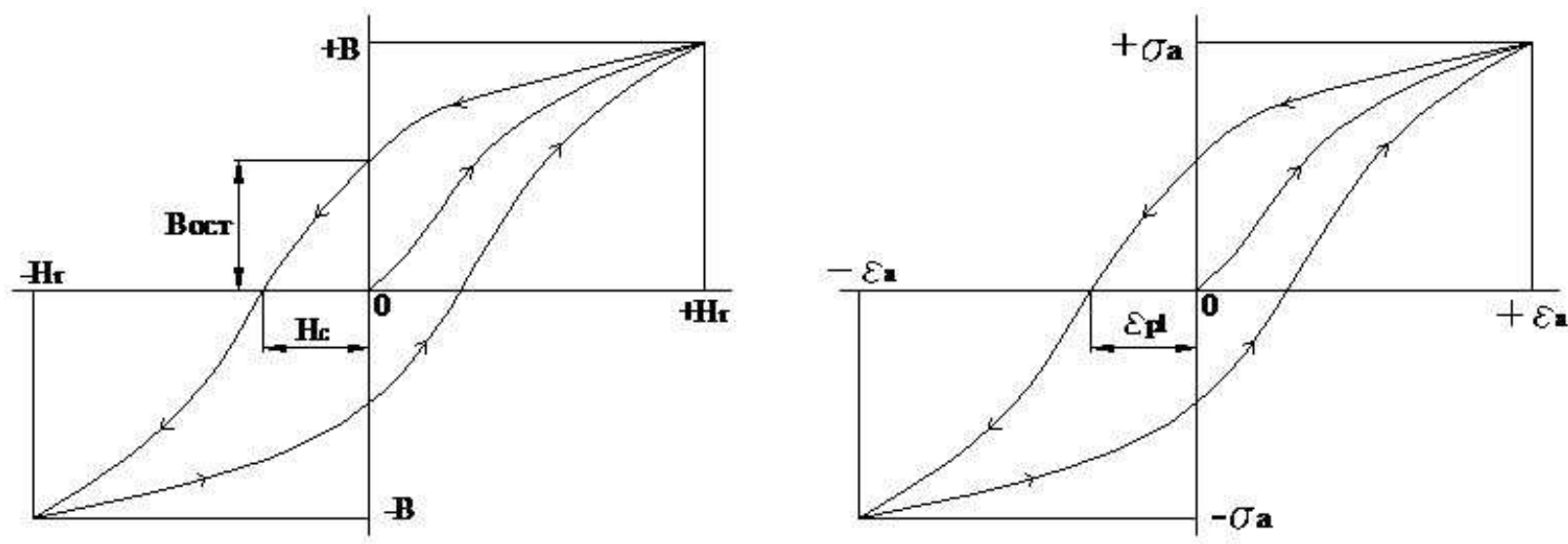

Рис. 2. Магнітна і деформаційна петлі гістерезису:

Нс - коерцитивна сила;

Вост - залишкова індукція;

К - циклічний коефіцієнт напруги; epl - залишкова деформація;

ба - амплітуда напруження;

$\mathrm{n}$ - циклічний коефіцієнт зміцнення
За наявності кореляційних залежностей між Hc i $\varepsilon p l$ за величиною коерцитивної сили можна вести контроль накопичення пошкоджень у металі, пружно-пластичної деформації металу, а також прогнозувати втомну довговічність металу. При знятті намагнічувального поля Н через незворотності процесів індукція не звертається на нуль, а залишається деяка величина залишкової індукції. Поява великої кількості дефектів у кристалічній решітці, напруги, які накопичуються за час експлуатації, викликають зменшення проникності і збільшення коерцитивної сили.

Початкові та кінцеві значення коерцитивної сили для кожної марки металу - це свої характерні константи. 
Кінцеве значення коерцитивної сили не залежить від кількості та властивостей експлуатаційних значень факторів, які призвели метал до руйнування. Обидві величини коерцитивної сили - у початковому стані ( поставка ) та у стані перед руйнуванням - так само значимі параметри для кожної марки металу, як, наприклад, межа міцності і межа плинності. Вони легко вимірюються 3 практичної точки зору.

Різниця між цими двома значеннями коерцитивної сили ( початковим та кінцевим ) рівнозначна експлуатаційному ресурсу металу. Прирощення від початкового до будь-якого проміжного поточного значення коерцитивної сили являє собою відпрацьований ресурс, а різниця поміж кінцевим та поточним залишковий ресурс за реальним станом накопиченої втоми.

Висновок. Втомні дефекти матеріалу металоконструкцій вантажних вагонів $\epsilon$ наслідком розвитку мікропошкодженості металу.

Крім того, руйнуванню металоконструкцій зазвичай передує пластична деформація. За вимірами коерцитивної сили можна кваліфікувати стан металу за еквівалентними питомими напруженнями i ступенем деградації металу.

На підставі кількісної оцінки втомного стану металу, в межах його неприпустимої втомної пошкодженості, можна приймати обгрунтовані рішення про черговість, доцільність та обсяги ремонту металоконструкцій вантажних вагонів.

Виходячи 3 цього об'єктивна оцінка стану металоконструкцій вантажних вагонів має формуватися 3 даних про їх поточний втомний стан. Знаходження зон, де мала або має місце пластична деформація, $\epsilon$ важливою задачею 3 контролю накопичених та попередження появи руйнівних пошкоджень у металоконструкціях вантажних вагонів.

\section{Список використаних джерел}

1. Бида, Г.В. Коэрцитиметрия в неразрушающем контроле [Текст] / Г.В. Бида // Дефектоскопия. - 2000. - № 10. - С. 3-28.

2. Фирсов, А.М. Основы неразрушающего контроля материалов и деталей машин [Текст]: учеб. пособие / А.М. Фирсов. - С.Пб.: Центр СПбГМТУ. - 2009. - 51 с.

3. Мельгуй, М.А. Магнитный контроль механических свойств сталей [Текст]: учеб. пособие / М.А. Мельгуй. - Наука и техника. - 1980. - 184 с.

4. Богачева, Н.Д. Расширение возможностей применения коэрцитивной силы [Текст] / Н.Д. Богачева // В мире неразрушающего контроля. - 2005. - № 2. - С. 8-10.

5. Михеев, М.Н. Магнитные методы структурного анализа и неразрушающего контроля [Текст] / М.Н. Михеев. - М.: Наука, 1993. - 252 с.

Рецензент д-р техн. наук, професор I.Е. Мартинов

Шевченко Костянтин Віталійович, старш. викл. кафедри вагонів.

Кравченко Сергій Анатолійович, слухач ІППК УкрДАЗТ.

Shevchenko K.V., Kravchenko S.A. 